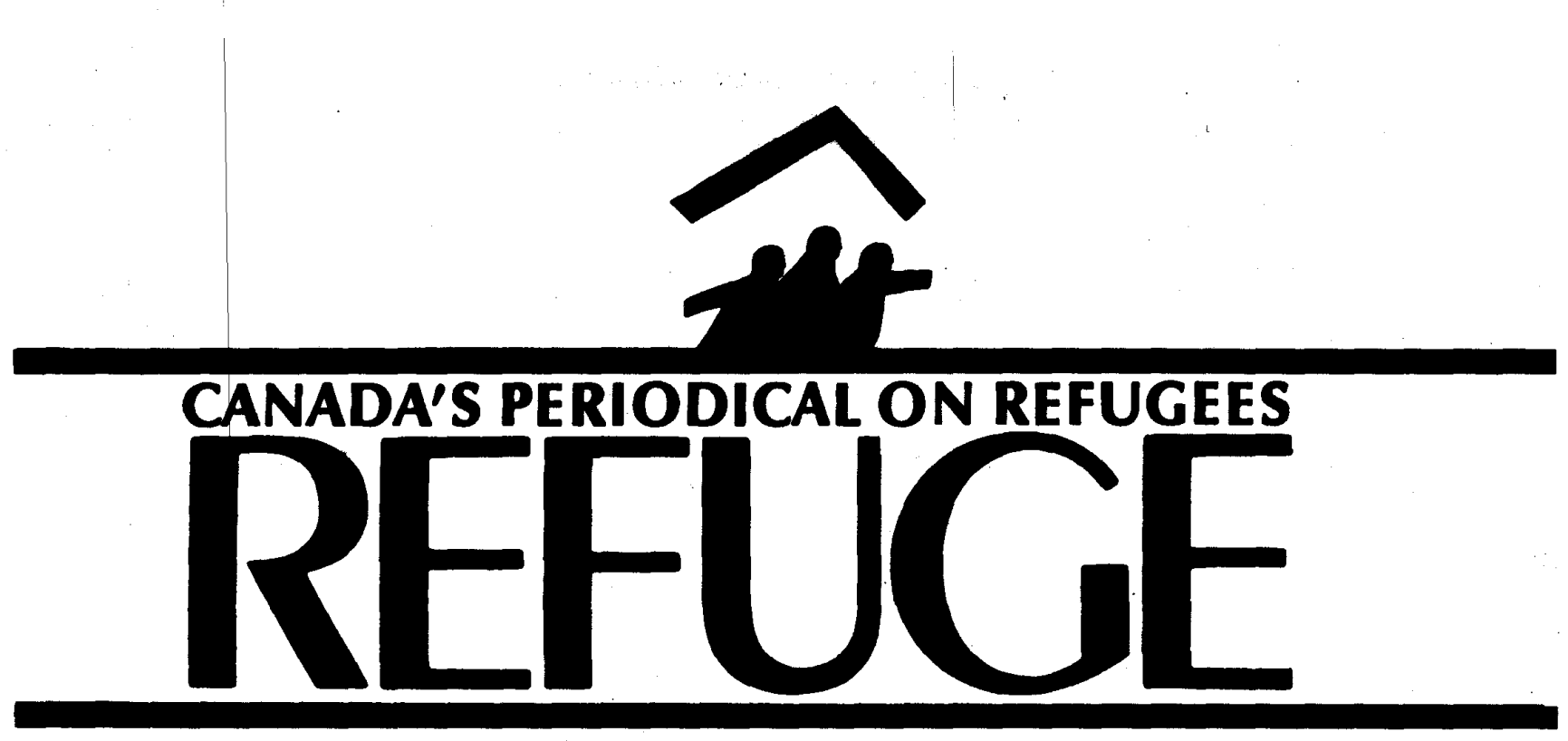

Vol. $16 \bullet$ No. 3

August 1997

\title{
Development-induCed Displacement
}

\section{Overview}

\author{
Peter Penz
}

Refugee studies are concerned with the displacement of people from their homes and native lands. Due to legal conventions defining refugees and their rights, the focus has generally been on people fleeing persecution and violence and seeking asylum in other countries. But much displacement occurs within countries and for reasons other than a fear of deliberate state victimization or violent disorder. In fact, very extensive displacement occurs from apparent efforts to do good. Development is broadly interpreted to consist of bettering the lives of people by improving their economic conditions. Violence is generally considered to be at least prima facie evil; people forced from their homes by violence are therefore victims of evil or of conflict that has escaped the bounds of civilized relations. Displacement by development, on the other hand, is an evil resulting from intentional political choices and, more specifically, the (at least alleged) pursuit of good.

The purpose of this issue of Refuge is to present instances of displacement due to development. In particular, two sources of development-induced displacement are evidenced in more than one of the articles. One source is dams, the other the Green Revolution.

Dams are an important form of infrastructure for development, especially in the generation of power for industrial development and in the development of irrigation for agricultural development. In this issue, the displacement effects of dams, as well as related issues, are discussed with reference to the Péligre Dam in Haiti by Philip Howard, to the Sardar Sarovar project on the Narmada River in India by Laurie Uytterlinde Flood and to the Kafin Zaki dam in Nigeria by Kole Ahmed Shettima. It is not only the huge reservoirs inundating often fertile and well populated land that cause dislocation, but also the irrigation canals and sometimes the degra-

\footnotetext{
Contents:

Overview Peter Penz ................................................................................ 1

Development-induced Displacement in Haiti Philip Howard............ 4

Sardar Sarovar Dam: A Case Study of Development-induced Environmental Displacement Laurie Uytterlinde Flood ........................ 12

Dam Politics in Northern Nigeria: The Case of the Kafin Zaki Dam Kole Ahmed Shettima

The Green Revolution: Socioeconomic Insecurity and Agricultural Displacement in India Mia Biasucci

Protecting Nature and Displacing People Peter Vandergeest .............. 28

How to Make Them Hear: Challenging Transnational Oil Interests in Ecuador's Amazon Region Malcolm Rogge ..................................... 32

The Ethics of Development-induced Displacement Peter Penz ........ 37
} 


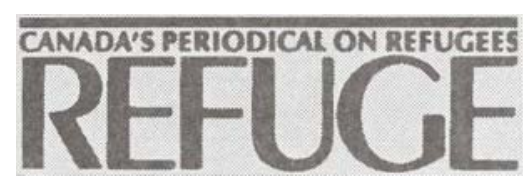

Centre for Refugee Studies Suite 322. York Lanes York University 4700 Keele Street. North York Ontario, Canada'M3J 1P3 Phone: (416) 736-5663 Fax: (416) 7365837 Emall: refuge@yorku.ca

Vo1.16. No.3 August 1997

Editor MICHAEL LANPHIER Guest Editor PETER PENz

Assistant Editors LYDIA SAWICKI MARK SWINDER

Refuge is dedicated to the encouragement of assistance to refugees by providing a forum for sharing information and opinion on Canadian and international issues pertaining to , Refuge was founded s founded in

It is published six times a year by the Centre for Refugee Studies, York University, Canada. Refuge is a nonprofit, independent periodical supported by private donations and by subscriptions. It is a forum for by subscriptions. It is a forum for discussion, and the views expressed
do not necessarily reflect those of its funders or staff.

All material in Refuge may be reproduced:without"permission Unless copyrighted orothei'w

dicated. Credit should be given to the author or source, i£named, and Rejuge.\}Sub1l1issio on. reJated issues are W-corrie $£^{\prime} 01$ publication consideration.

Currentsubscription rates for one year (six issues) a),'e: canada Cdn.\$50; all oth er countries U.S. $\$ 60$. (Cheques must be drawn on a Canadian O \{ia U.S. b ) Currept volume,single $\sim 1$-1es are available at $\$ 10$ per copy.

Please enclose your purchase o er Jpa¥fert $1 \backslash 1$

ISSN 0229-

5113 dation of downstream fisheries. Moreover, Vandergeest brings out that nature

customary land tenure is questioned as protection has displaced forest-dwellers land titles are required for compensation (or, in the case of those threatened by eviction to make room for those being resettled, for the retention of land in the face of the pressure to find land to resettle legally recognized land-holders who are displaced).

The other theme is the Green Revolution. As mentioned, dams can increase agricultural production through irrigation. But agricultural development involves many other elements, including new seeds and the use of fertilizer and pesticides, i.e. those of the Green Revolution, as discussed in the article by Mia Biasucci on India and by Philip Howard about the highlands of southwest Haiti. The

Green Revolution was supposed to be scale-neutral, i.e. be of equal benefit to small farmers as to big farmers. However, it turned out to benefit the better endowed farmers disproportionately and actually impoverished poor farmers, thus displacing many of them.

Displacement is caused by diverse development activities. Examples are the impact on forest-dwellers from reserving forests for industrial and commercial logging, from converting forests to agricultural uses and from introducing mining and the chemical pollution associated with it, the impact

on fisherfolk and paddy farmers from coastal shrimp-farming, or the impact on shanty-town dwellers from urban redevelopment. Another one, discussed by Malcolm Rogge with reference to Amazonian Ecuador, is petroleum extraction. Since in this case indigenous people are involved, there are issues of land rights as well as the life-and-death matter of a lack of immunity to diseases carried by the incoming labour force. As happened historically in the "New World" as a whole, displacement can take the deadly form of depopulation.

Even efforts to contain the environmentally destructive effects of development can force people from their homes, if carried out in a ruthless or thoughtless manner. Pete worldwide.

It should be noted that, although the focus of this issue has been on poorer countries, the processes referred to are not absent here in Canada. The James Bay hydro project in Quebec is an example of ams displacing indigenous people in Canada, and the economic pressure on family farms reflects in part the impact of technology and corporate organization on agriculture and those who make their living from it.

The cases and forms of developmentinduced displacement presented in this issue of Refuge suggest a classification. A basic distinction to be made is between direct and indirect displacement. Direct displacement takes the form of eviction or efers to the process of being forced out in a direct manner, such as by the inundation of a valley or by legal prohibitions that take away basic rights to livelihood, such as the right to collect forest products.

Indirect displacement occurs through more circuitous chains of development impacts. Thus the Green Revolution did not directly displace poor farmers, but made it difficult for many of them to earn their living. This happened when they could not afford

the Green-Revolution technology, but experienced the price-reducing effect of greater agricultural output due to improved productivity on the part of those who did utilize Green-Revolution technology. This process often combines with political processes that give big farmers privileged access to agricultural infrastructure such as irrigation. The result is frequently that poor selling their property and moving into shanty-towns on urban fringes. Indirect displacement can also occur as a result of environmental consequences, such as erosion resulting from destructive logging practices that lead to landslides and to river flooding or chemical pollution that kills fish and thus undermines the livelihood of fisher communities. Displacement directly induced by development alone

Refuge, Vol. 16, No.3 (August 1997) farmers have no reasonable alternative to 
is globally massive; when we add indirect displacement the phenomenon is truly ubiquitous.

The distinction between direct and indirect displacement is too crude for some of the cases dealt with in this issue. Thus, Peter Vandergeest deals with displacement that is not due to development as conventionally conceived, but due to efforts to protect nature against the destructive effects of development. Such destruction constitutes the first-order effects; remedial policies then are second-order processes; to the extent that these uproot people, such displacement is a thirdorder effect and could be deemed to represent indirect displacement. However, it often takes the form of evictions, which constitute direct displacement. (The phenomenon is actually more complicated. To the extent that nature conservation is merely to earn income from tourism, it is more like conventional development after all, and evictions are first-order effects of tourism development.)

The complications that this analysis gives rise to is something that Mia Biasucci has tried to deal with by proposing two distinctions: one between direct and indirect displacement and the other between primary and secondary displacement effects. Direct displacement refers to evictions and the like and indirect displacement to migration forced through the deterioration of economic and environmental conditions. On the other hand, "primary" and "secondary" draw a distinction in terms of the proximity to development initiatives. Thus the firstorder effects of the Green Revolution are primary and second- and third-order effects are secondary. This double distinction leads her to focus on "indirect primary displacement" in the form of the livelihood impacts of the Green Revolution on farmers and on "direct secondary displacement," which are lower-order effects outside the agricultural sector but involve eviction-type displacement. It is thus useful to separate the directness of the displacement process from its proximity to development initiatives.
All of the articles involve normative critiques of displacement. They constitute at least negative prescriptions, i.e. not to engage in the kind of development policies that displace people. The third-and second-last articles, furthermore, also involve positive prescriptions to avoid displacement. Peter Vandergeest advocates the integration of established livelihoods with conservation and ultimately the replacement of destructive development constrained by highly selective conservation with a broader environmentally protective approach. Malcolm Rogge outlines an approach to the empowerment of those threatened by dislocation. Instead of state policy reform, this prescription is to reduce the inequalities of power in the conflicts and struggles that displacement involves and is addressed more to non-governmental organizations.

By involving critique and prescription with respect to development and displacement, these articles enter the terrain of development ethics. It is the purpose of my concluding article to probe into this terrain in a more explicit fashion by addressing some ethical questions concerning developmentinduced displacement. The concern there will be with possible justifications of development policies and projects that uproot people. More generally, it will, in the briefest of terms, provide pointers for moral evaluations of development policies with reference to the issue of displacement.

Are there alternatives? Two positive prescriptions offered in the following articles have already been referred to (widening environmental protection and empowering those vulnerable to displacement). More generally, an approach to development that prioritizes basic needs, the aims of local communities, and the environmental sustainability of economic activities, rather than big business, heavy industry and export production, can be expected to result in much less dislocation. In fact, it can be expected to contribute to the opposite of vulnerability to displacement, namely locational security. It is, however, unlikely that even a bottomup approach to development will completely prevent dislocation. Compensation and environmentally and culturally sensitive rehabilitation for direct displacement, therefore, remain central issues as does assistance to those threatened or actually impacted by indirect displacement. Moreover, the problem of international debt and the entanglement in economic globalization may mean that the prevention of displacement is less feasible now than it was when development was still predominantly a national project (and states were much more in a position to choose not to pursue development policies that massively uproot people). This, too, means that alleviating the harm of development-induced displacement is as important as trying to avoid it in the first place.

Peter Penz is Associate Professor, Faculty of Environmental Studies, York University, Toronto.

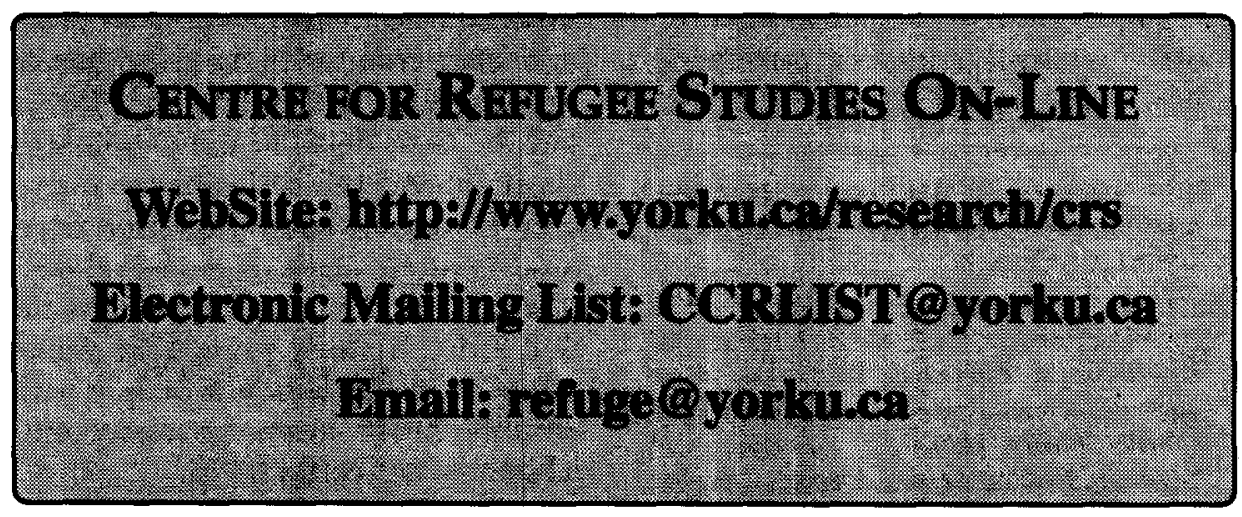

